\title{
In memoriam Professor Dr. Philipp A. Schnabel (1953-2021)
}

\author{
Björn LDM Brücher ${ }^{1,2,3, *}$ \\ ${ }^{1}$ Theodor-Billroth-Academy ${ }^{\circledR}$, Germany, USA \\ ${ }^{2}$ INCORE, International Consortium of Research Excellence of the Theodor-Billroth-Academy ${ }^{\circledR}$, Germany, USA \\ ${ }^{3}$ Department of Surgery, Carl-Thiem-Klinikum, Cottbus, Germany
}

Received 16 February 2022, Accepted 16 February 2022

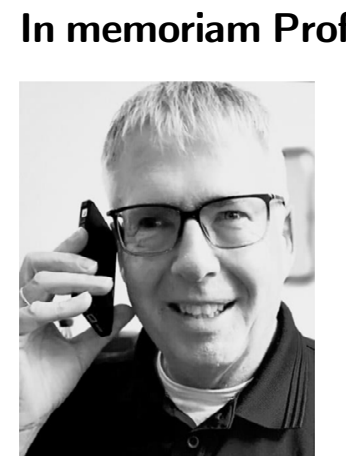

Ssor Dr. Philipp A. Schnabel

IN MEMORIAM

Professor Dr. med. Philipp Schnabel (1953-2021)

Professor Dr. med. Philipp Albert Schnabel passed away on May 31, 2021 at the age of 67 years. He served on the 4open Editorial Board and was a valued long-term colleague and friend.

Philipp was born in Kassel, Germany, on May 24, 1953, studied Medicine in Gießen, Germany and started his career as a scientific assistant in cardiac surgery, University of Gießen, and completed his thesis in orthopedics in 1983. He was interested in clinical and emergency medicine. From 1980 until 1992, Philipp was scientific assistant under the renowned physiologist Professor Dr. Hans-Jürgen Bretschneider (1922-1993) at the University of Göttingen, Germany. There Philipp performed his habilitation and obtained his Ph.D. in 1993.

In 1992, Philipp focused his expertise in electron microscopy and ultrastructure of the heart and lungs to the Institute of Pathology under Professor Dr. h.c. Martin Otto at the University of Heidelberg. Dr. Philipp Schnabel passed his examination and was a Board-certified pathologist in 2001. It is remarkable that Philipp had his second habilitation and enlarged his expertise in General and Special Pathology in 2003 at Heidelberg. He was appointed Professor in 2006.

In 2014, Philipp went to the University of Homburg (Universitätsklinikum des Saarlandes und Medizinische Fakultät der Universität des Saarlandes) (Director: Prof. Dr. R.M. Bohle) and received his Professorship there in 2017.

The scientific work of Professor Dr. Philipp Schnabel included more than 130 original articles in international journals, numerous reviews and book chapters. Philipp was awarded the Ernst-Derra-Award of the German

*Corresponding author: b-bruecher@gmx.de
Society of Thoracic, Heart and Vascular Surgery (Deutschen Gesellschaft für Thorax-, Herz- und Gefäßchirurgie) in 1995 and the Franz-Köhler-Award of this society in 1997.

Professor Philipp Schnabel retired in 2018 and took time with his family and for traveling.

We remember Philipp with sincere gratitude and respect as an excellent pathologist, scientist, teacher, and good friend and a kind human being.

Our deepest condolences to his family, especially his wife, Jutta, and his kids Maike and Julius.

On behalf of the 4open Editorial Board.

\section{Conflict of interest}

The author reports the following conflicts of interest: Björn LDM Brücher is Editor-in-Chief in Life SciencesMedicine of 4open by EDP Sciences. This in memoriam obituary and information was not peer-reviewed.

\section{Acknowledgments}

The widow of Professor Dr. Philipp A. Schnabel, Jutta Kinkel-Schnabel kindly provided the picture and deserves credit. Professor Dr. Kerstin Amann, Neuropathologist from Erlangen published a nice German obituary, why this should be mentioned [1].

\section{Ethics}

This article and its content are not sponsored.

\section{Credit}

Credit Picture: Cordially the picture of Professor Dr. Philipp A. Schnabel was provided by his wife, Jutta Klinkel-Schnabel. 


\section{References}

1. Amann K (2021), Philipp A. Schnabel, Der Pathologe. https://doi.org/10.1007/s00292-021-00994-x.

Cite this article as: Brücher BLDM (2022), In memoriam Professor Dr. Philipp A. Schnabel (1953-2021). 4open, 5, 7. 